Winter 2013

\title{
The Pursuit of "Voluntary" Tax Compliance in a Globalized World
}

Jennifer Hepp

Indiana University Maurer School of Law, jhepp@indiana.edu

Follow this and additional works at: https://www.repository.law.indiana.edu/ijgls

Part of the International Law Commons, and the Tax Law Commons

\section{Recommended Citation}

Hepp, Jennifer (2013) "The Pursuit of "Voluntary" Tax Compliance in a Globalized World," Indiana Journal of Global Legal Studies: Vol. 20 : Iss. 1 , Article 15.

Available at: https://www.repository.law.indiana.edu/ijgls/vol20/iss1/15

This Note is brought to you for free and open access by the Law School Journals at Digital Repository @ Maurer Law. It has been accepted for inclusion in Indiana Journal of Global Legal Studies by an authorized editor of Digital Repository@Maurer Law. For more information, please contactrvaughan@indiana.edu.

\section{$\Psi$}

JEROME HALL LAW LIBRARY

INDIANA UNIVERSITY

Maurer School of Law
Bloomineton 


\title{
The Pursuit of "Voluntary" Tax Compliance in a Globalized World
}

\author{
JENNIFER HEPP*
}

\begin{abstract}
Globalization diminishes the U.S. government's ability to enforce the income tax by undermining the Internal Revenue Service's information advantage. U.S. taxpayers are able to hold their money overseas, where the IRS's information-gathering abilities are at their lowest ebb, with increasing ease. Tax treaties aim to rectify the IRS's information disadvantage abroad by encouraging foreign countries, particularly tax havens, to share information with the IRS. However, these treaties have been largely ineffective. Instead, it may be time for the United States to go the way of other developed countries and reform its tax structure to reduce reliance on the income tax and adopt, instead, a value-added tax.
\end{abstract}

\section{INTRODUCTION}

Globalization threatens the ability of the United States Internal Revenue Service (IRS or the tax bureau) to enforce the income tax by undermining the tax bureau's ability to gather information about taxpayers. The IRS relies on information reporting to elicit "voluntary" (rather than compelled) payment of income taxes. ${ }^{1}$

One major way that globalization undermines the IRS's information-gathering abilities is by providing more opportunities for U.S. residents to hold funds in foreign financial institutions. ${ }^{2}$ By taking their money overseas-"tax flight"-U.S. residents are able to avoid the

* Executive Submissions Editor, Indiana Journal of Global Legal Studies, J.D. Candidate, 2013, Indiana University Maurer School of Law. I would like to thank Professor Ajay Mehrotra for his invaluable guidance and my parents, Denny Hepp and Kathy Gordon, for their loving support.

1. See Leandra Lederman, Tax Compliance and the Reformed IRS, 51 U. KAN. L. REV. 971, 972-76 (2003).

2. See Steven A. Dean, The Incomplete Global Market for Tax Information, 49 B.C. L. REV. 605, 626 (2008). Another method for avoiding U.S. taxation is through expatriation. See id. at 627 .

Indiana Journal of Global Legal Studies Vol. 20, Issue 1 (2013)

(C) Indiana University Maurer School of Law 
reach of the IRS's information-gathering capacity. ${ }^{3}$ As money drifts away from the United States and flows into tax havens, the IRS's information-gathering abilities quickly fade-virtually eliminating the tax bureau's most important enforcement tool. ${ }^{4}$

Due to tax flight, the IRS is often unable to rely on its traditional, cost-effective enforcement mechanism of third-party reporting by domestic financial institutions. Alternative enforcement mechanisms like the following are more costly and less effective than third-party reporting: relying on international information-exchange agreements; paying the tax havens for information; ${ }^{5}$ or switching from the income tax to a consumption tax, such as a sales tax or value-added tax (VAT). Switching to a consumption tax, which is generally characterized as "regressive"-that is, low- and middle-income individuals pay more taxes in proportion to their income than high-income individuals-could have the unintended effect of widening the already expansive U.S. wealth gap. ${ }^{6}$ The historical development of the income tax demonstrates that third-party reporting and withholding are vital to the tax's success; 7 without structural enforcement, switching to an entirely different tax, most likely the VAT, may be the United States' only viable option.

This note argues that globalization has and will continue to undermine enforcement of the income tax-which relies on third-party information reporting-and that the best alternative is a progressive consumption tax. This note examines the history of the income tax and the effects of globalization, and demonstrates that the structure of income tax administration-reliance on third-party reporting-makes

\footnotetext{
3. See id. at $628-30$.

4. See id.

5. See Steven A. Dean, Philosopher Kings and International Tax: A New Approach to Tax Havens, Tax Flight, and International Tax Cooperation, 58 HASTINGS L.J. 911, 913-15

6. Income inequality in the United States has been on the rise since the late-1970s. TAX PRogressivity and INCOME INEQUALITY 4 (Joel Slemrod ed., 1996); Ian Ayres \& Aaron S. Edlin, Don't Tax the Rich. Tax Inequality Itself, N.Y. TIMES, Dec. 18, 2011 ("In 1980, the wealthiest 1 percent of Americans made 9.1 percent of our nation's pre-tax income; by 2006 the share had risen to 18.8 percent . . . in after-tax dollars, our wealthiest. 1 percent over this same period went from receiving 7.7 percent to 16.3 percent of our nation's income."). Cf. Arthur S. Alderson \& François Nielsen, Globalization and the Great U-Turn: Income Inequality Trends in 16 OECD Countries, 107 AM. J. Soc. 1244, 1246 (2002) (explaining that income inequality in the United States began to rise around 1970 after declining since the 1930s). The widening wealth gap led scholars to argue that "at some point the concentration of economic power could undermine the democratic requisite of dispersed political power" because the wealthy are able to use their vast resources to influence elections. Ayres \& Edlin, supra.
} (2007).

7. See, infra, Section I. C-D. 
the income tax particularly susceptible to evasion through tax flight. Part I traces how third-party reporting became rooted in the income tax system at four key points in U.S. history: the Civil War, the enactment of the Sixteenth Amendment, World War I (WWI), and World War II (WWII). Part II explains how globalization has undermined enforcement of the income tax, and explores alternative enforcement mechanisms with particular emphasis on the VAT.

\section{DeVelopment of ThiRD-Party Reporting}

Each year, the IRS audits less than 1 percent of individual taxpayers and assesses penalties to evaders in amounts that are mere portions of the actual taxes owed to the IRS. ${ }^{8}$ The consequences for evasion are, on average, too low to cause rational individuals to comply, ${ }^{9}$ and yet most taxpayers comply by accurately reporting and paying their full tax burdens. 10 This observation has led to the characterization of the U.S. income tax as "voluntary."11

Referring to the U.S. income tax as a voluntary tax is not entirely accurate, however. The overall probability of audit does not accurately reflect the risk that an individual considers when determining whether to attempt income tax evasion. For example, if an employer submits its employees' annual salaries to the IRS and an employee omits the salary income from her own return, the personal return "will be flagged for further scrutiny with a probability much closer to $100 \%$ than to $2 \%$." 12 Thus, the typical income taxpayer whose salary income is subject to withholding reports her tax liability accurately because of the expectation (with near 100 percent certainty) of being caught for evasion. ${ }^{13}$

U.S. income tax compliance rates are among the highest in the

8. See, e.g., Lederman, supra note 1 , at 973.

9. See id.

10. See U.S. Gov'T ACCOUNTABILITY OfFICE, GAO-07-391T, TAX CoMpliance: MULTIPLE APPROACHes ARE NEEDED to REDUCE THE TAX GAP 8 (2007) [hereinafter GAO] (estimating that the 2001 tax gap was $16 \%$, or $84 \%$ compliance).

11. "Voluntary compliance" refers to the tax code placing the burden of calculating and reporting income tax liability on the entity that is responsible for payment. Leandra Lederman, Statutory Speed Bumps: The Roles Third Parties Play in Tax Compliance, 60 STAN. L. REV. 695, 711 (2007) [hereinafter Speed Bumps].

12. Joel Slemrod, Trust in Public Finance 9 (Nat'l Bureau of Econ. Research, Working Paper No. 9187, 2002) [hereinafter Trust], available at http://www.nber.org/papers/w9187. The IRS uses a computer matching system to compare returns between entities with corresponding income and expenses.

13. See id. 
world due to third-party withholding and information reporting. ${ }^{14}$ Third-party withholding ${ }^{15}$ and information reporting ${ }^{16}$ contribute to a taxpayer's "visibility." 17 The more visible a taxpayer is-that is, the more available her tax-sensitive information is to the IRS-the more likely she is to voluntarily comply with taxation. ${ }^{18}$ Assuming that third parties have incentives to accurately report or withhold and remit, rather than collude with taxpayers, ${ }^{19}$ or not report at all, taxpayers under the third-party umbrella have minimal opportunity to avoid taxation. ${ }^{20}$

Compliance rates tend to be highest where a domestic corporation is responsible for reporting or withholding income. ${ }^{21}$ Third-party reporting requirements essentially regulate the behavior of institutions, usually corporations, rather than individuals. ${ }^{22}$ The size and visibility of corporations eases the IRS's administrative task. ${ }^{23}$ Additionally, corporations are more likely to voluntarily comply with tax laws than individual taxpayers because they "have significant economic incentives to do so." 24

The sections that follow address how third-party withholding and reporting became firmly rooted in the U.S. income tax structure, arguing that history demonstrates that the IRS's ability to administer

14. See Lederman, supra note 1, at 973-76.

15. For example, an employer withholding a portion of an employee's wages and forwarding tax payments to the IRS.

16. For example, a financial institution recording interest earned and providing the IRS with the information.

17. See GAO, supra note 10 , at 12 (demonstrating that compliance rates increase as taxpayers are subject to greater "visibility").

18. Id.

19. See Speed Bumps, supra note 11, at 724-28. The Internal Revenue Code distinguishes between persons that have incentives that align with the IRS's enforcement goals and those who have incentives to evade. See id. For example, tortfeasors generally have an incentive to minimize the settlement while tort victims have an incentive to maximize the settlement, so the IRS can rely on the settlement as an accurate reflection of medical costs. See id. However, if the third-party has an incentive to collude with the taxpayer, such as if the tortfeasor and the taxpayer were related parties, the IRS may not be able to rely on the settlement as an accurate reflection of costs. See id.

20. A taxpayer whose income tax is withheld has virtually no opportunity to avoid the income tax and a taxpayer whose tax liability is reported to the tax bureau is able to avoid the tax as an initial matter but faces a high risk of audit. See Trust, supra note 12, at 9.

21. See GAO, supra note 10 , at 12.

22. Joel Slemrod, The Economics of Corporate Tax Selfishness, 57 NAT'L TAX J. 877, 891 (2004) ("The IRS correctly believes that it is much more efficient to collect and monitor taxes remitted by a smaller group of employers compared to taxes remitted by a hundred million or so employees."); Edward K. Cheng, Structural Laws and the Puzzle of Regulating Behavior, 100 NW. U. L. REV. 655, 666 (2006).

23. See Cheng, supra note 22.

24. Id. 
the income tax to a wide tax base hinges on its ability to gather information from third parties.

\section{A. Civil War: The First Income Tax}

The first income tax was implemented in 1861 as a temporary, emergency measure to provide desperately needed revenue for the Civil War. ${ }^{25}$ The Civil War income tax was unique in that it fell on only the highest-earning residents, ${ }^{26}$ which led to its characterization as a "class tax."27

At the time, the government relied on consumption taxes, ${ }^{28}$ and did not have the necessary infrastructure to enforce the income tax. ${ }^{29}$ Implementation of the income tax required "a new and robust administrative agency, one capable of mounting a nationwide collection effort." 30 Whereas consumption taxes were paid by businesses that already had the infrastructure in place to keep records as well as an existing relationship with the government, income taxes had to be collected from a new set of people-the individual taxpayers themselves. Due to administrative difficulties, Congress's first attempt to enact the income tax had no practical effect. ${ }^{31}$

The Revenue Act of 1861 enacted the first national income tax, ${ }^{32}$ but

25. The ability to quickly raise revenue was a matter of national security because the revenue directly funded the war efforts as well as maintained the country's creditworthiness so that the United States could borrow funds to make up for revenue shortfalls. See N. P. Hill, Payment of the National Debt, 143 N. AM. REV. 209, 213 (1886) ("Clearly, this country has no army or navy in existence of which foreign nations need be very much afraid. What they respect is our power to raise, equip, and maintain armies and navies, and they know that this power becomes greater in proportion to our progress in freeing ourselves from financial clogs and encumbrances.").

26. See generally Joseph J. Thorndike, Reforming the Internal Revenue Service: A Comparative History, 53 ADMIN. L. REV. 717 (2001). Some proponents of the income tax framed the tax as fair because it taxed those most able to pay and those who enjoyed the greatest benefits from America's stability. Id. at 720. An article from the New York Times argued that the income tax was designed "to place the heaviest burden upon that portion of the people who have the largest material stake in the country and the nearest interest in the integrity, public faith and lasting stability of the Government; the men of money and of productive stocks and other income paying securities." Id. (quoting The Internal Tax Bill, N.Y. TIMES, Mar. 4, 1862, at 4) (internal quotation marks omitted).

27. See Charlotte Twight, Evolution of Federal Income Tax Withholding: The Machinery of Institutional Change, 14 CATO J. 359, 364 (1995).

28. A consumption tax is a tax on spending, whereas an income tax is a tax on earnings.

29. See Thorndike, supra note 26 , at 719 .

30. Id.

31. See id. at 721 .

32. Revenue Act of 1861, ch. 45, 49 Stat. 309. 
left the details of enforcement up to the U.S. Treasury. ${ }^{33}$ The failure to provide an enforcement mechanism proved damning; Secretary of the Treasury Salmon P. Chase recognized that the nation was desperate for war funding, ${ }^{34}$ but was not willing to take a risk on wasting the Bureau of Internal Revenue's (BIR's) ${ }^{35}$ resources on implementing the income tax because he believed that enforcement would be too expensive. ${ }^{36}$

Dissatisfied, Congress enacted the Revenue Act of 1862, which dealt with the enforcement and administration problems by shifting the enforcement burden to third parties through a prescribed withholding mechanism. The Revenue Act required withholding at the source of the income for certain taxpayers. ${ }^{37}$ Corporations were required to withhold taxes on dividends and interest, and the federal government was required to withhold taxes from government employees' salaries. ${ }^{38}$ For taxpayers not falling into these categories, the BIR relied on voluntary compliance and grappled with ways to encourage taxpayers to self-report their own incomes accurately and make timely payments. ${ }^{39}$

33.

[I]t shall be the duty of the President ... to appoint one principal assessor and one principal collector in each of the States and Territories of the United States, and in the District of Columbia, to assess and collect the internal duties or income tax imposed by this act, with authority in each of said officers to appoint so many assistants as the public service may require, to be approved by the Secretary of the Treasury. The said taxes to be assessed and collected under such regulations as the Secretary of the Treasury may prescribe.

Id. $\S 50$ (emphasis added).

34. See S. P. Chase, Report of the Secretary of the Treasury on the State of THE FinANCES, S. Doc. No. 37-2, at 12 (2d Sess. 1861) ("To meet these increased [military] demands, arising almost wholly from the increase of the army and navy and the increase of pay and rations beyond the original estimates, large additional appropriations have been and will be necessary.").

35. The Bureau of Internal Revenue, or BIR, is the forerunner to the present-day IRS. 36.

Considering ... how large a proportion of incomes, after the deductions sanctioned by law, will fall within the exemption limit of $\$ 800$ a year; and considering also what numerous questions will certainly perplex its assessment and collection, [the Secretary of the Treasury] respectfully submits to the consideration of Congress whether the probable revenue affords a sufficient reason for putting in operation, at great cost, the machinery of the act.

CHASE, supra note 34, at 15. See also Thorndike, supra note 26, at 721.

37. Revenue Act of 1862, ch. 119, 12 Stat. 432 (1862). Another significant difference between the two acts is that the Revenue Act of 1862 implemented the first progressive rate income tax. See id. at 473. Taxpayers with incomes greater than $\$ 600$ faced a tax rate of $3 \%$ and those with incomes over $\$ 10,000$ were taxed at a rate of $5 \%$. Id.

38. Id. at 472 .

39. One attempted method was publicizing tax assessments to create social pressure to file accurate tax returns: publication "afford[s] every tax-payer an opportunity of ascertaining what returns his neighbors have made. He is interested in these returns, 
Due in part to public dissatisfaction with the inconsistent enforcement of the income tax (some taxpayers self-reported very low incomes) and general enforcement difficulties, Congress let the income tax lapse after 1871.40 Excise taxes and tariffs still formed the core of the government's tax policy. ${ }^{41}$

\section{B. The Sixteenth Amendment}

Two decades after the close of the Civil War, Congress responded to calls for more progressive taxation by enacting the first peacetime income tax in $1894 .{ }^{42}$ However, just one year later, the Supreme Court declared the tax unconstitutional in Pollock v. Farmers' Loan and Trust Company. ${ }^{43}$ In Pollock, the Court held that certain provisions of the Tax Act of 1894 were unconstitutional because they established a "direct"

because the burden of the national duties is a common one, and every person should be required to pay his due proportion of it." Thorndike, supra note 26, at 727-28 (quoting Publication of the List of Incomes, N.Y. TIMES, Feb. 7, 1865, at 4) (internal quotation marks omitted). An editorial published in the New York Times argued that publication was necessary to address the problem of tax evasion because auditing was ineffective as the BIR was either unable or, due to corruption, unwilling to ferret out and punish evaders. See Letter to the Editor, Publication of the Income Tax Lists, N.Y. TIMES, Jan. 20, 1865. The author believed that noncompliance was a rampant problem, stating that "[h]undreds of instances can be pointed out in that single list where men report their incomes very far below what every man of common sence [sic] knows them to be." Id. The author also believed that publication could alert the community to noncompliance because one could ascertain "that the returns in an immense number of cases are utterly unreliable and flagrantly false" with just "a glance at the list." Id. Evasion would violate the community's sense of fairness and evoke social repercussions to the evader. See Thorndike, supra note 26, at 727. Public support for the income tax waned with the end of the Civil War, Twight, supra note 27 , at 367 , and Congress prohibited publication in 1870 in an attempt to avoid losing further support, notwithstanding concerns about noncompliance, Thorndike, supra note 26 , at 728 .

40. See supra text accompanying note 39 (publication revealed evasion through falsified self-reports). Allegations of corruption within the BIR were another source of public dissatisfaction with the income tax. See Thorndike, supra note 26, at 729. The BIR's decentralized structure eventually brought administrative problems, including allegations of corruption and mismanagement, and these administrative problems combined with "waning support for steep wartime taxation" led to a push for reform of the BIR during the mid-1860s. Id. at 719 . The BIR survived the reform movement, but the income tax did not. See id.

41. See Thorndike, supra note 26 , at 722 .

42. See id. at 737-38 (noting that "Congress resisted such [tax reform] efforts until the 1890 s, when a steep economic downturn helped galvanize support for tariff and tax reform, especially among southern and western Populists."). Congress authorized a $2 \%$ tax on incomes over $\$ 4,000$, which only reached the richest $10 \%$ of U.S. residents and citizens. Id.

43. Pollock v. Farmers' Loan \& Trust Co., 157 U.S. 429 (1895), aff'd on reh'g, 158 U.S. 601 (1895). 
tax without allocating the revenue from the tax to the states according to population. ${ }^{44}$ Specifically, the Court interpreted the provisions establishing a tax on dividends, interest, and rent as direct taxes on property. 45

Undaunted, income tax supporters continued lobbying for another income tax with the hope of challenging the Supreme Court. ${ }^{46}$ Instead, progressives struck a political compromise, substituting passage of the 1909 corporate income tax ${ }^{47}$ and the Sixteenth Amendment for another income tax bill. ${ }^{48}$ The Sixteenth Amendment, which became effective in 1913, eliminated the requirement that Congress apportion direct taxes among the states by population, authorizing Congress to levy taxes on income from property, like interest, dividends, and rent, without apportionment. 49

The 1913 Act, a tax bill passed in response to the Sixteenth Amendment, authorized more expansive withholding than the Revenue Act of 1862.50 Whereas the Civil War tax bill required only federal government employers to withhold taxes, the 1913 Act required all employers, financial institutions, and other organizations "making payments of more than $\$ 3,000$ in interest, salary, or other fixed income to an individual ... to withhold tax; in some cases, even smaller amounts triggered withholding." 51

\section{WWI: Tax Base Expansion and Adoption of Third-Party Reporting}

The 1913 Act laid the groundwork for the United States' modern

44. Id. at 607-08.

45. Id.

46. There was a strong populist push within the Senate to pass legislation similar to that invalidated in Pollock in order to confront the Supreme Court, but President Taft sought to avoid a challenge that might undermine the Supreme Court's authority. Thorndike, supra note 26, at 738-39. See also Twight, supra note 27, at 367-68.

47. The corporate income tax did not face the same constitutional challenge as the individual income tax because it was billed as an excise tax on the privilege of doing business. Twight, supra note 27 , at 368 n. 8 .

48. See Thorndike, supra note 26 , at 739 . The corporate income tax was formulated by GOP leaders, including President Taft, to "siphon off support for general income taxation" and preserve GOP unity by fracturing the coalition of Democrats and western Republicans formed with the agenda of passing a general individual income tax again. $I d$, at 738 . The Sixteenth Amendment was also part of the GOP's compromise, but the GOP leaders thought that the constitutional amendment would be a minor concession and did not even expect ratification by the states. $I d$. at 739 .

49. U.S. Const. amend. XVI.

50. Revenue Act of 1913, ch. 16, § II(D), 38 Stat. 114, 168-69 (1913). See also Thorndike, supra note 26 , at $740-41$.

51. Thorndike, supra note 26 , at $740-41$. 
income tax policy by instituting a broad withholding requirement; and the WWI tax acts brought the country a step closer to its modern tax policy by expanding the taxable base ${ }^{52}$ and enforcing the tax through third-party information reporting. Income tax developments from the WWI era would be solidified during WWII when the tax base was expanded even further and information reporting by employers was replaced with withholding.

Revenues from the 1913 tax began to drop as early as 1914, so in 1916, a year before the United States entered World War I, Congress turned to the income tax to make up for the revenue shortfall by raising the rates on the existing tax base..$^{53}$ Later, Congress raised revenue by lowering exemption levels to expand the tax base to reach 20 percent of households - a much broader tax base than ever before. ${ }^{54}$

The rapid rise in the tax base and revenue collections stretched the BIR's administrative capacity. ${ }^{55}$ The BIR responded by tripling the size of its individual income tax unit in 1918 and then doubling the unit's employees again in 1919. ${ }^{56}$ Despite the staff increases, the agency was still falling behind in enforcement: "In 1918, the commissioner [of the BIR] told a congressional committee that 4 million individual returns for 1916 and 1917 were still unaudited." 57 With most of its growth in staff and the majority of audits taking place at its headquarters, the BIR became increasingly centralized. 58

52. That is, by lowering exemption levels and making more individuals subject to the income tax, or at least filing requirements.

53. Thorndike, supra note 26 , at 741-42.

54. See Ajay K. Mehrotra, American Economic Development, Managerial Corporate Capitalism, and the Institutional Foundations of the Modern Income Tax, 73 LAW \& CONTEMP. PROBS. 25, 51-52 (2010) ("At the height of the World War I tax regime, the exemption level dropped to $\$ 1000$ ( $\$ 2000$ for married couples), normal rates soared to $6 \%$ for the first $\$ 4,000$ of income above exemption levels and $12 \%$ for all income beyond $\$ 4,000$, and surtax rates skyrocketed to a top rate of $65 \%$.").

55. See Thorndike, supra note 26 , at 743-47.

56. Id. at 745 .

57. Id.

58. See id. at 744. "The growth in headquarters staff reflected the centralized process for dealing with income tax returns, all of which were sent to Washington for mathematical checking and many of which were audited." Id. "The relatively small number of field agents, moreover, made it impossible to audit an adequate number of returns . . . 5\% of individual returns and $15 \%$ of corporate returns required further examination, but the agency's field staff was too small to undertake the task." Id.

In 1917, as the agency began to gear up for war taxation, it employed 524 headquarters staff and 4,529 field staff. By 1918, total staff had grown to 9,600, and it rose further to roughly 14,000,18,000,20,000, and 21,000 in each of the subsequent years. Headquarters staff grew more quickly than field staff, increasing almost fourteen times during the period, compared to just a three-fold increase for field staff. 
Withholding was not used as a primary means of enforcement for long. In 1917, Congress switched from third-party withholding to third-party information reporting. ${ }^{59}$ More than one explanation has been offered for why withholding was replaced with third-party information reporting. One account argues that withholding was too burdensome for the BIR, ${ }^{60}$ while another argues that withholding was eliminated to reduce popular criticism of the income tax. ${ }^{61}$ Information reporting shifted the responsibility for actually paying the tax back to the individual taxpayer while maintaining the BIR's information advantage. ${ }^{62}$ The switch did not solve the administrative burden, however, because even the inflow of information was difficult for the BIR to deal with given its limited administrative capacity. ${ }^{6}$

\section{WWII: The Mass Base Tax and Adoption of Withholding}

Initially, the income tax was levied only on those with the highest incomes, but due to the outbreak of WWII, the income tax's reach was expanded to many more residents and became a "mass tax" rather than a "class tax." 64 The taxable base expanded substantially-increasing from 3.9 million tax returns filed in 1939 to 42.6 million in 1945-as did income tax revenue -rising from $\$ 2.2$ billion in 1939 to $\$ 35.1$ billion in $1945 .{ }^{65}$ At the end of the war, 90 percent of American workers filed tax returns and 60 percent actually paid income tax.66 Prior to 1941 , the Treasury Department had always received fewer than eight million individual income tax returns each year, but by 1941 the number of returns received had risen to fifteen million and, in 1943, officials expected that number to rise to thirty-five million returns. ${ }^{67}$

To administer the tax to a hugely expanded base, Congress adopted

Id. at 743-44.

59. Id. at 744 .

60. Id. at 744 (Congress switched from third-party withholding to third-party information reporting in 1917 because "stoppage-at-source techniques for collecting the income tax ... proved a cumbersome process for the agency.").

61. "Based on public criticism, Treasury Secretary William G. McAdoo reported that it would be very advantageous to ... do away with the withholding of income tax at the source' because it would 'eliminate a great deal of criticism which has been directed against the law." Twight, supra note 27, at 369 (quoting U.S. Treasury Department 1916: $19)$.

62. See Thorndike, supra note 26 , at 744 .

63. See id.

64. See id. at 753.

65. Id.

66. Id. at 754 .

67. Twight, supra note 27 , at 370 . 
withholding once again. ${ }^{68}$ Congress passed the Current Tax Payment Act in 1943 and implemented withholding, which has remained in place ever since. ${ }^{69}$ Nonetheless, some "BIR officials were notable skeptics of the plan, arguing that withholding would require too many additional personnel and expensive mechanization."70 This skepticism was well-founded. Withholding was eliminated during WWI due to its unpopularity with taxpayers and because the BIR lacked the necessary administrative capacity.

Withholding did prove to be an effective enforcement mechanism during WWII, unlike in previous periods. ${ }^{71}$ Public opinion, administrative capacity, and economic structure variables appear to have converged to make the initial adoption and subsequent institutionalization of withholding effective. ${ }^{72}$

The BIR's administrative capacity had expanded by $1943 .{ }^{73}$ At that point, the IRS had greater experience with withholding because it had used withholding for the Social Security Act since 1935,74 and for the

68. See id. at 369 .

69. Id.

70. Thorndike, supra note 26 , at 754 .

71. See id.

72. The public may have been more receptive to withholding during WWII than during WWI because, in addition to the patriotism boost that public opinion likely received during both periods, the WWII period also offered tax cancellation. See Twight, supra note 27 , at 375 . The Ruml Plan, proposed in 1942 by Beardsley Ruml who was chairman of the Federal Reserve Bank of New York at the time, would cancel most of an individual's tax liability for the year to avoid a year with double tax liability, which would have occurred with an immediate switch to withholding's pay-as-you-go structure. See id. Charlotte Twight argues that Ruml's proposal to forgive one year's income tax was "absolutely critical to-and perhaps the proximate cause of-public acceptance of income tax withholding in 1943." Id.

The public may also have been more receptive to the income tax in general.

When asked why withholding from the 1913 Act was abandoned:

Treasury official Paul's response . . . captured the resistance-eroding effect of an institutional foot in the door: "At that time taxes collected under an income tax system was [sic] something new in this country and I think it is fair to say there was some resistance to collecting at the source .... We were not used to being income tax payers, but now we have gone along for a period of about 30 years under the income tax system and $I$ think the analogy is far from being very relevant."

Id. at 383 (quoting U.S. House Hearings 1943: 82).

73. See id. at 382-83. An advocate for withholding explained that withholding for the Social Security Act was already taking place and that the government already had "a system of reporting at the source by employers, a force of internal revenue field agents, and so forth. Accordingly, we have the makings of an adequate tax machine. Most of the parts are there." Id. at 383. (quoting U.S. House Hearings 1941: 345) (internal quotation marks omitted).

74. Id. 
Victory Tax since 1942. The Social Security Tax provided the BIR and its employees with the necessary experience collecting a tax at the source and the Victory Tax established the "essential machinery" for withholding. ${ }^{75}$ Additionally, improvements in education levels at the beginning of the twentieth century resulted in increasingly well-educated and trained public officials, causing the government's administrative capacity to expand. ${ }^{76}$ Finally, accounting innovations eased the BIR's administrative burden. ${ }^{77}$

Structural changes in the U.S. economy made withholding a more viable enforcement mechanism by channeling taxpayers into employment that subjected individuals to reporting and withholding, thus improving the reporting and withholding capacity of third parties. Industrialization, "the pronounced shift from agriculture to large-scale manufacturing," facilitated tax administration "by helping supplant household production and barter transactions with a more liquid cash economy."78

During the same period, corporations became increasingly able to act as third-party enforcers of the income tax, allowing the tax bureau to shift administrative responsibilities to corporations. ${ }^{79}$ The new corporate management structure-separation of ownership and control-adopted by corporations made them well-suited to carry out third-party reporting and withholding. Whereas "traditional, often family-owned, companies combined the responsibilities of ownership and control," modern businesses employed "managerial corporate capitalism," which consisted of separating the tasks of management and ownership. ${ }^{80}$ Managerial tasks, including monitoring and coordination, were carried out by "a hierarchy of salaried managers who generally had little equity stake in the businesses they operated." 81 This separation of interests made modern corporations, which were run by "business bureaucrats," prime candidates to take on some of the administrative burden of the income tax. ${ }^{82}$ Furthermore, the unprecedented size of corporations as organizational units made them well-poised to conduct withholding and information reporting. ${ }^{83}$ "The

75. Id. at 383 .

76. Mehrotra, supra note 54, at 36-37.

77. See id. at 46.

78. Id. at 37 .

79. See id. at 46 .

80. Id. at 41 .

81. Id.

82. See id.

83. See id. at 41-42. One significant period was the "great merger movement," which took place from 1895 to 1904 , and consisted of consolidation of corporations through 
economies of scale that were driving mass production and distribution ... facilitate[d] income-tax collections" by driving corporate growth and allowing large corporations to spread out the overhead costs required to undertake withholding and reporting among many employees. ${ }^{84}$

Today, the IRS utilizes sophisticated information-reporting techniques to ferret out taxpayers that do not comply with the rules regarding personal income tax on dividends and interest. ${ }^{85} \mathrm{By}$ computer matching third-party information reports and taxpayer returns, the IRS can narrow the field of likely evaders. ${ }^{86}$ This method decreases the cost of enforcement by: (1) reducing the number of audits necessary by targeting audits at the class of taxpayers that are most likely to have evaded, and (2) increasing the incentive to accurately report by increasing the likelihood that a taxpayer that misstates their taxable income will be caught. ${ }^{87}$

\section{Globalization's EFFECT ON INCOME TAX ENFORCEMENT AND THE VAT'S APPEAL}

Voluntary income tax compliance is positively correlated with "visibility." 88 When the taxpayer is entirely responsible for calculating and paying her own taxes, such as those earning rents and royalties or farm income, the compliance rate is just 46 percent. ${ }^{89}$ The compliance rate jumps to over 90 percent when the income is subject to some form of information reporting..$^{90}$ The compliance rate increases further when the income is subject to substantial information reporting, rising to over 95 percent. ${ }^{91}$ Expectedly, compliance reaches its peak of 99 percent when the income is subject to substantial information reporting and

mergers and acquisitions that took place at "a remarkable, breakneck pace" and created colossal organizations. $I d$.

84. See id. at 50.

85. See Joel Slemrod, Cheating Ourselves: The Economics of Tax Evasion, 21 J. EcoN. PERSP. 25, 35 (2007) ("An extremely wide variety of transactions must be reported to the IRS, including interest, dividends, real estate transactions, rents, sales of securities, and wages. In 2002-2003 some 1.3 billion such reports were received (96 percent electronically) and computer-matched with taxpayer records; the program entailed some 4.3 million taxpayer contacts and resulted in additional assessments amounting to almost $\$ 5$ billion.").

86. See id. at $35-38$.

87. See id.

88. See Internal Revenue Service, TAX GaP MaP for TAX Year 2001 (2007), available at http://www.irs.gov/pub/irs-utl/tax_gap_update_070212.pdf. "Visibility" refers to the level of third-party monitoring that the income is subjected to. See id.

89. See id.

90. See id.

91. See id. 
withholding.92 Taxpayers who fall outside of the withholding and reporting scheme, such as self-employed individuals, however, have significantly lower compliance rates. ${ }^{93}$

Steven Dean, a Professor of Tax Law and Policy at Brooklyn Law School with expertise in the areas of tax havens and international taxation, ${ }^{94}$ has summarized the problem that the IRS faces as follows:

The United States . . . has found itself facing a growing disparity between the information it collects domestically and the information it is able to acquire from abroad. At the same time, globalization and technological change have made the ability to acquire useful extraterritorial tax information more important than ever. ${ }^{95}$

The problem for tax administration is two-fold: (1) the global economy creates incentives to engage in transactions abroad, whether for legitimate business reasons or to take advantage of tax havens; and (2) the IRS's information-gathering abilities are at their lowest ebb outside of the United States. ${ }^{96}$

Without coordinated tax policies among governments, "the potential mobility of economic activity makes it extremely difficult for governments to exploit monopoly positions over much of their tax bases, thereby greatly contributing to the distortions created in the course of raising tax revenue." 97 That is, the global economy enables taxpayers to go outside of their country of residence and seek out low-tax jurisdictions (tax havens). 98

The United States tax system is unlike those of the majority of industrialized countries. ${ }^{99}$ Rather than relying on an income tax, over 130 countries have adopted "[t]he value-added tax (VAT") [as] a mainstay of [their] fiscal systems . . ., including every Organisation for Economic Cooperation and Development ('OECD') country except the United States." 100 A VAT is a type of consumption tax that taxes the

92. See id.

93. Id.

94. Steven Dean, BROOKLYN LAW SCHOOL, https://www.brooklaw.edu/faculty/directory/ facultymember/biography.aspx?id=steven.dean (last visited Nov. 13, 2012).

95. Dean, supra note 2, at $\mathbf{6 7 2 .}$

96. See generally id.

97. Id. at 2-3.

98. See id.

99. See Itai Grinberg, Where Credit Is Due: Advantages of the Credit-Invoice Method for A Partial Replacement Vat, 63 TAX L. REV. 309, 309 (2010).

100. Id. at 309. 
"value added" at each stage of production. In contrast, a retail sales tax, a consumption tax commonly used at the state level in the United States, taxes only the final sales price. Michael Graetz, Professor of Tax Law at Columbia Law School, ${ }^{101}$ argues that a VAT is easier to enforce than a retail sales tax because VAT revenues can be "collected regularly throughout the year from companies at all levels of production, rather than just from retailers." 102

Another distinct feature of the U.S. income tax is that "the United States is the only economically developed country that taxes its citizens abroad on their foreign income." 103 The IRS is, generally, able to collect from citizens employed by U.S. multinational corporations because those corporations, like domestic corporations, report wage data to the IRS. ${ }^{104}$ Enforcement becomes more difficult when the corporation is not United States-based, however, because the corporation does not report wage data to the IRS. 105 Without a third-party reporter, "[t]he IRS might not even be aware of the overseas citizen's existence, and even if the IRS is aware, it might have significant difficulty determining the individual's income and tax liability." 106

Globalization has not forced the United States to change its personal income tax policies because the United States has a large economy and faces fewer international pressures than countries with small open economies. ${ }^{107}$ In small open economies, actors engage in cross-border transactions with much greater frequency than actors in larger, more closed economies. Due to their increased reliance on the global economy, countries with small, open economies were the first to change their tax policies to address the pressures of globalization. In particular, this required adopting a consumption tax and lower income tax in conformance with the rest of the international community in order to avoid incentivizing the movement of transactions to tax-favored jurisdictions.

101. Michael J. Graetz, COLUMBIA LAW ScHOOL, http:/www.law.columbia.edu/fac/ Michael_Graetz (last visited Nov. 14, 2012).

102. Michael J. Graetz, 100 Million Unnecessary Returns: A Fresh Start for the U.S. Tax System, 112 Yale L.J. 261, 288 (2002).

103. Michael S. Kirsch, Taxing Citizens in A Global Economy, 82 N.Y.U. L. REv. 443, 443 (2007).

104. Id. at 497 .

105. Id.

106. Id. (footnote omitted).

107. See James R. Hines, Jr. \& Lawrence H. Summers, How Globalization Affects Tax Design 3 (Nat'l Bureau of Econ. Research, Working Paper No. 14664, 2009). "The relative ease of international trade, capital movement and communication makes it possible for production to locate in many places around the world and for tax burdens to be avoided through international transactions." $I d$. at 2 . An open economy is characterized by many cross-border transactions. 
However, "[g]lobalization means that in some sense all countries are becoming smaller," and large countries can expect to face the same international pressures experienced by small countries and must therefore change their tax systems in similar ways. ${ }^{108}$ Thus far, the United States has managed to maintain its reliance on income taxes due to its large, and relatively closed, domestic economy. ${ }^{109}$ But the rising number of cross-border transactions is straining the efficacy of third-party reporting. ${ }^{110}$ In the future, the United States is likely to adopt tax policies that are more like those used by today's small, open economies, like the VAT.111

In particular, globalization is undermining the government's ability to rely on third-party reporting and withholding because taxpayers are able to "hide their money in offshore tax havens."112 The loss in tax revenues is substantial, amounting to approximately $\$ 50$ billion a year. ${ }^{113}$ Globalization further burdens the IRS by increasing the cost of enforcement, ${ }^{114}$ because the IRS is unable to shift the cost of information gathering onto third-parties. Instead, the IRS has pursued a costly strategy of elaborate investigations and audits. In one famous case, the IRS “used a private detective to 'entertain' a banker while the contents of his briefcase were photographed to uncover the identities of tax cheats." 115 It is too expensive to discover and investigate all tax evaders in this manner.

To ease its enforcement burden, the IRS has attempted to elicit voluntary compliance from taxpayers directly through the Offshore Voluntary Disclosure Program (OVDP).116 OVDP targets "people hiding offshore accounts" and encourages them to, according to IRS Commissioner Doug Shulman, "come in and get right with [the IRS] before [the IRS] find[s] you."117 If a taxpayer discloses through OVDP, he or she may face lower penalties than if they were caught by the IRS. ${ }^{118}$ After processing 95 percent of disclosures, the IRS has collected

\footnotetext{
108. Id. at 3.

109. See id. at 13-14, 18-20.

110. Dean, supra note 2, at 672 .

111. See Hines \& Summers, supra note 107, at 18-20.

112. Steven A. Dean, Get the Havens to Help, NAT'L L.J., Sept. 11, 2006, at 1.

113. Id.

114. See id. at 1-2.

115. Id. at 1.

116. See IRS Offshore Programs Produce \$4.4 Billion to Date for Nation's Taxpayers; Offshore Voluntary Disclosure Program Reopens, IRS, http://www.irs.gov/uac/IRSOffshore-Programs-Produce-\$4.4-Billion-To-Date-for-Nation\%E2\%80\%99s-Taxpayers;-

Offshore-Voluntary-Disclosure-Program-Reopens (last updated Aug. 4, 2012).

117. Id.

118. Baker \& Mckenzie Voluntary Disclosure Steering Committee, New 2011 Offshore Voluntary Disclosure Initiative, 22 J. Int'l Tax. 20, 24-26 (2011) (explaining that under
} 
$\$ 3.4$ billion from the 2009 program. ${ }^{119}$ This amounts to 6.8 percent of the estimated $\$ 50$ billion kept in offshore tax havens each year. ${ }^{120}$ Overall, the program's progress has been limited: "the really bad tax cheats remain cheats and unless there is a 'stick' to bring these people in, it is questionable how effective this program will be."121

The IRS has also attempted to ease its administrative burden through international information-exchange agreements. The United States and other members of the OECD compiled a list of low- or no-tax jurisdictions, "tax havens," and urged them to exchange information to help OECD countries collect their unpaid income taxes. ${ }^{122}$ So far, "[t]he governments of tax havens, by and large, have responded with empty promises to cooperate." 123 Even if tax havens that have signed Tax Information Exchange Agreements (TIEAs), like "Antigua \& Barbuda, Aruba, the Bahamas, the British Virgin Islands, the Cayman Islands, Guernsey, the Isle of Man, Jersey, and the Netherlands Antilles," complied with the agreements, the usefulness would be limited because "many TIEAs narrowly define the circumstances in which an exchange is required."124 For example, the Cayman Islands is only required to provide the United States with information under the terms of the TIEA "if the IRS has a 'valid reason' for suspecting a specific taxpayer of criminal tax evasion." 125

To encourage information reporting, Professor Dean proposes paying tax haven countries to report to the IRS. ${ }^{126}$ Specifically, Dean suggests the tax-haven government could share "a fixed percentage of any part of the lost $\$ 50$ billion that tax havens help them to recover."127 Attempting to create monetary incentives to disclose information about income could cause the governments of tax-haven countries to hold out and demand greater payment. It could even encourage other countries to adjust their laws to transform their country into a tax haven that

OVDP, taxpayers owe penalties amounting to the lesser of "[e]ither an accuracy or delinquency penalty ... for all years ... [and] information return and FBAR penalties, [or] a penalty equal to $20 \%$ of the amount in foreign bank accounts or entities in the year with the highest aggregate account or asset value").

119. IRS, supra note 116.

120. See Dean, supra note 112. Dean estimates that $\$ 50$ billion in revenue is lost to offshore tax havens each year. Id. $\$ 3.4$ billion divided by $\$ 50$ billion is $6.8 \%$.

121. Baker \& Mckenzie, supra note 118 at 27.

122. See Dean, supra note 112 at 1-2. "Most of the countries named (e.g., the Bahamas) were no surprise, but other inclusions (war-torn Liberia) and omissions (OECD member Switzerland) stood out." Id. at 2 .

123. $I d$.

124. Kirsch, supra note $103,500-01$.

125. Id. at 501 n.254.

126. Dean, supra note 112 at 2.

127. Id. 
could share in the revenue.

Alternatively, the United States could follow the lead of countries with small, open economies and adopt a consumption tax, like a VAT, ${ }^{128}$ rather than relying almost exclusively on income taxes at the federal level. In a global economy, consumption taxes are easier to administer than income taxes because "expenditures have relatively clear geographic associations, reducing the potential for international tax avoidance and generally reducing the mobility of the tax base compared to alternatives such as personal income taxes or source-based business taxes including the corporate income tax."129

However, consumption taxes have met political resistance in the United States because, in practice, they are "considerably less progressive than income tax alternatives" and "movement away from income taxation and in the direction of greater expenditure taxation is typically associated with less equal after-tax distributions of income."130 Instituting an expenditure tax could have a particularly distortive effect on income equality in the United States because income disparity between the rich and the poor is so great today:

By just about any measure income has become significantly less evenly distributed in the United States over the past three decades. There is considerable controversy over the extent to which changes to income distribution in wealthy countries can be attributed to the growth of international trade and investment, though the evidence . . . strongly suggests that globalization has contributed significantly to income inequality. ${ }^{131}$

Acknowledging concerns about progressivity, Professor Graetz proposed a combination of a VAT and an income tax in his article, 100 Million Unnecessary Returns: A Fresh Start for the U.S. Tax System. ${ }^{132}$ A 10 to 15 percent VAT in combination with a 25 percent income tax on incomes over $\$ 100,000$ "would produce revenues roughly equivalent to the current income tax." 133 Importantly, the income tax would not apply to incomes of $\$ 100,000$ or less, and Graetz's "proposal, unlike the 'flat tax' and 'fair tax' proposals, would not dramatically shift the tax burden

128. Hines \& Summers, supra note 107 at 3.

129. Id.

130. Id. at 19 .

131. Id. at 5 .

132. Graetz, supra note 102 at 282-83.

133. Id. at 282 (footnote omitted). 
away from high-income families to middle- and lower-income families." 134 If progressivity is still a concern, the Congress could adjust tax expenditures to increase programs that benefit the poor. For example, policymakers could allocate more revenue for "education and training programs] that support income creation by less affluent members of the population." 135 Moreover, incorporating a VAT into the federal tax structure and "[r]educing income taxes [would] make the U.S. tax system more favorable to investments by both U.S. residents and foreigners. Our income tax would be lower than that of most other nations, and our taxes on consumption would be comparable to those imposed elsewhere."136

\section{CONCLUSION}

By WWII, third-party reporting and withholding emerged as dominant enforcement strategies because they dramatically improved compliance while shifting part of the administrative burden from the IRS to independent entities, like employers and financial institutions. Withholding transfers the decision of whether to comply with the income tax from the taxpayer to a third party. The result is a highly effective enforcement structure because the party with the incentive to evade - the taxpayer-loses her ability to evade (assuming that the withholding party has an incentive to comply with the law). Third-party reporting has a similar effect, but to a somewhat lesser extent. An individual whose income is subject to information reporting loses control over the information that the government receives, but maintains control over the actual payment of the tax. The result is that the taxpayer can still choose not to pay her taxes, but she then faces a heightened risk of detection because the government has a record of her income and tax liability.

Between WWI and WWII, the BIR and the economy underwent important structural changes that made withholding and information reporting increasingly viable enforcement mechanisms. The BIR's administrative capacity benefited from better-educated bureaucrats and new accounting methods. At the same time, the development of large corporations with division of ownership and streamlined accounting processes that had incentives to abide by government regulations ${ }^{137}$

134. Id. at $282-83$.

135. Hines \& Summers, supra note 107 at 19.

136. Graetz, supra note 102 at 286.

137. Third-party reporting and withholding are effective enforcement mechanisms when the third-party has an incentive to transmit accurate information to the government, but are ineffective when the third-party has an incentive to collude with the taxpayer. See 
allowed the tax bureau to shift more and more of its administrative costs to third parties.

Today, the economy is undergoing another substantial structural change that is dramatically affecting income tax enforcement. Just as the advent of corporations made the income tax viable through structural enforcement mechanisms, globalization and the resulting increased mobility of capital is depriving the IRS of third-party information reporting and is making consumption taxes increasingly viable. Consumption taxes are often associated with regressive taxation and widening income inequality, but the United States has the capacity to implement unique solutions to revive progressive taxation. Both adopting a VAT to supplement the income tax and narrowing the income tax base to only those earning high incomes could address the administrative problems associated with third-party reporting abroad without placing too great a burden on low- and middle-income taxpayers.

Speed Bumps, supra note 11, at 712 . When the third-party has an incentive to accurately report the taxpayer's income, the government can "free ride" by relying on third-party reporting or withholding for enforcement, rather than auditing the transaction. See id. Cf. id. at 717 (explaining that the tax code gives preferential treatment to income that is subject to third-party monitoring). 